\title{
Jurist-Diction
}

Volume 2 No. 6, November 2019

Histori artikel: Submit 2 September 2019; Diterima 2 Oktober 2019; Diterbitkan online 1 November 2019.

\section{Keberlakuan Sanksi Pidana terhadap Perusahaan yang Tidak Memiliki Izin Menggunakan Tenaga Kerja Asing}

\author{
Ahmad Fairus \\ fairuss.ahmad@yahoo.com \\ Universitas Airlangga
}

\begin{abstract}
Indonesia is one of the countries that incorporated in the MEA. The existence of the Asean Economic Community (MEA) at the end of 2015 caused the influx of foreign workers (TKA) to flow in and out in Indonesia. This causes Indonesia to be obliged to adapt to various fields, one of which is the field of labor. The presence of foreign workers who will later occupy positions or positions in companies in need is a challenge that must be faced by local workers. On Peraturan Presiden No. 20 Tahun 2018 the plan to use foreign workers (RPTKA) as well as a permit to employ foreign workers. Whereas according to Undang-Undang No. 13 Tahun 2003 Tentang Ketenagakerjaan must have a written permit from the Minister or a designated official (IMTA) after having an RPTKA which is a requirement process that must be met and will be subject to criminal sanctions in accordance with Pasal 185 ayat (1) Undang-Undang Ketenagakerjaan if it violates these provisions.

Keywords: Use of Foreign Worker (TKA); RPTKA; IMTA.
\end{abstract}

\begin{abstract}
Abstrak
Indonesia merupakan salah satu negara yang tergabung dalam program Masyarakat Ekonomi Asean (MEA). MEA merupakan salah satu komponen yang bertujuan untuk menciptakan kawasan ASEAN yang stabil, makmur dan memiliki daya saing tinggi, kompetitif dengan perkembangan ekonomi yang merata, serta mengurangi angka kemiskinan. Adanya Masyarakat Ekonomi Asean (MEA) pada akhir tahun 2015 menyebabkan arus keluar masuknya tenaga kerja asing (TKA) semakin gencar di Indonesia. Hal tersebut menyebabkan Indonesia wajib untuk beradaptasi dengan berbagai bidang, salah satunya bidang tenaga kerja. Kehadiran tenaga kerja Asing (TKA) yang nantinya akan menduduki jabatan atau kedudukan di perusahaan-perusahaan yang membutuhkan merupakan tantangan yang harus dihadapi oleh tenaga kerja lokal. Dalam Peraturan Presiden No. 20 Tahun 2018 recana penggunaan tenaga kerja asing (RPTKA) sekaligus merupakan izin mempekerjakan TKA. Sedangkan menurut Undang-Undang No. 13 Tahun 2003 Tentang Ketenagakerjaan menyatakan bahwa setiap Tenaga Kerja Asing harus memiliki ijin tertulis dari Menteri atau pejabat yang ditunjuk (IMTA) setelah memiliki RPTKA yang merupakan proses persyaratan yang harus dipenuhi dan akan dikenakan sanksi pidana sesuai dengan Pasal 185 ayat (1) Undang-Undang Ketenagakerjaan jika melanggar ketentuan tersebut.
\end{abstract}

Kata Kunci: Penggunaan Tenaga Kerja Asing (TKA); RPTKA; IMTA.

\section{Pendahuluan}

Indonesia merupakan salah satu negara yang tergabung dalam program Masyarakat Ekonomi Asean (MEA) yang dimulai pada akhir tahun 2015. MEA merupakanasalah satu komponen dalam visi ASEAN 2020 yang bertujuan untuk menciptakanakawasan ASEAN yang stabil, 
makmur, dan memiliki daya saing tinggi, kompetitif dengan perkembangan ekonomi yang merata, serta mengurangi angka kemiskinan. Salah satu cara yang ditempuh adalah dengan membebaskan perdagangan yang tercantum dalam MEA. Kawasan ASEAN diharapkan dapat meningkatkan integrasi ekonominya dengan adanya program MEA. ${ }^{1}$ MEA diyakini dapat membawa manfaat bagi masyarakat Indonesia dimana masyarakat juga harus memiliki daya saing di antara kawasan negara-negara ASEAN. Namun masih ditemukan perbedaan kemampuan dari setiap negara anggota yang menjadi kendala bagi MEA dalam meningkatkan perekonomian yang merata di kawasan ASEAN. Negara yang tergolong masih memiliki pertumbuhan ekonomi rendah di kawasan ASEAN yaitu Cambodia, Laos, Myanmar, dan Vietnam. Perbedaan kondisi ekonomi negara mempengaruhi dua aspek MEA, yaitu arus bebas barang, dan arus bebas tenaga kerja. Kebijakan yang diberlakukan pada arus bebas barang adalah menghapus hambatan tarif (bea cukai) dan non tarif pada perdagangan. Hal tersebut bertujuan supaya barang bisa bergerak bebas dari satu negara ke negara lainnya. Sedangkan pada aspek arus bebas tenaga kerja, negara diwajibkan menyediakan tenaga kerja yang berkualitas. Di Indonesia sendiri ada beberapa hal penting yang harus ditinjau pada aspek ketenagakerjaan, seperti kualitas sumber daya manusia di tingkat pendidikan dan keahlian yang masih dinilai belum memadai dalam menyediakan tenaga kerja di era MEA. Rendahnya kualitas tenaga kerja sangat mempengaruhi daya saing di antara negara ASEAN yang akan membuat Indonesia rentan di era MEA. Mengingat bebasnya arus tenaga kerja menunjukkan bahwa tenaga kerja asing akan leluasa di Indonesia dan tenaga kerja lokal akan terancam. ${ }^{2}$

Seiring dengan berlakunya MEA, Indonesia juga beradaptasi dengan berbagai bidang, salah satunya yaitu bidang tenaga kerja. ${ }^{3}$ Tenaga Kerja Asing (TKA) dapat lebih mudah memasuki pasar Indonesia. Oleh karenanya, diperlukan kebijakan

\footnotetext{
${ }^{1}$ Imroatus Sa'adah, 'Indonesia Dalam Masyarakat Ekonomi ASEAN (MEA) Dalam Perspektif Ibnu Khaldun', Skripsi,(Universitas Islam Negeri Sunan Kalijaga 2018).[1].

${ }^{2}$ ibid. [7].

${ }^{3}$ Suhandi, 'Pengaturan Ketenagakerjaan Terhadap Tenaga Kerja Asing Dalam Pelaksanaan Masyarakat Ekonomi Asean Di Indonesia',(2016) 21 Perspektif.[136].
} 
pemerintah yang dapat memberikan kesempatan bagi pekerja dalam negeri untuk dapat bersaing dengan pekerja asing di Indonesia. Berdasarkan Pasal 1 angka 13 Undang-Undang Ketenagakerjaan, TKA merupakan warga negara asing pemegang visa dengan maksud bekerja di wilayah Indonesia. Dalam penggunaan TKA pada aspek keamanan dan aspek legalitas, Undang-Undang No. 13 Tahun 2003 Tentang Ketenagakerjaan mensyaratkan pemberi kerja TKA untuk mendapatkan izin tertulis dari Menteri Ketenagakerjaan dan Transmigrasi atau pejabat yang ditunjuk. Izin yang dapat diberikan untuk jangka waktu paling lama 1 (satu) tahun dan bisa diperpanjang disebut Izin Mempekerjakan TKA (IMTA). Kehadiran TKA adalah sebuah kebutuhan dan merupakan tantangan yang harus dihadapi karena Indonesia membutuhkan TKA terutama di sektor perekonomian guna menciptakan daya saing yang kompetitif. Adapun demikian, pada praktiknya penggunaan TKA pada pemberi kerja atau perusahaan dapat menimbulkan problematika tersendiri.

Presiden Joko Widodo menandatangani Peraturan Presiden Nomor 20 Tahun 2018 tepat pada tanggal 26 Maret 2018 yang dinilai telah menuai banyak kontroversi di masyarakat. Peraturan Presiden No. 20 Tahun 2018 diketahui banyak memuat ketentuan-ketentuan yang berbeda dari peraturan sebelumnya yaitu ini menggantikan Peraturan Presiden No. 72 Tahun 2014 tentang Penggunaan Tenaga Kerja Asing serta Pelaksanaan Pendidikan dan Pelatihan Tenaga Kerja Pendamping yang dicabut dan dinyatakan tidak berlaku berdasarkan Pasal 38 huruf a Peraturan Presiden TKA. ${ }^{4}$ Salah satu contoh aturan yang berbeda adalah pengesahan Rencana Penggunaan TKA (RPTKA) sekaligus sebagai izin mempekerjakan TKA (IMTA), sebelumnya RPTKA digunakan sebagai dasar untuk memperoleh IMTA. Peraturan Presiden No. 72 Tahun 2014 juga mewajibkan pemberi kerja TKA mengantongi IMTA kecuali bagi perwakilan negara asing yang menggunakan TKA sebagai pegawai diplomatik dan konsuler. Dengan adanya Peraturan Presiden No. 20 Tahun 2018 yang baru, pemberi kerja tidak lagi wajib memiliki IMTA untuk mempekerjakan TKA dengan jabatan direksi atau komisaris pada pemberi Kerja

${ }^{4}$ Monika Suhayati, 'Kontroversi Perpres Nomor 20 Tahun 2018 Tentang Penggunaan Tenaga Kerja Asing', (2018) 10 Kajian Singkat Terhadap Isu Aktual Dan Strategis.[1]. 
TKA, pegawai diplomatik dan konsuler pada kantor perwakilan negara asing atau TKA pada beberapa jenis pekerjaan yang dibutuhkan pemerintah. ${ }^{5}$ Sedangkan dalam Undang-Undang No. 13 Tahun 2003 Tentang Ketenagakerjaan menyatakan bahwa setiap Tenaga Kerja Asing harus memiliki izin tertulis dari Menteri atau pejabat yang ditunjuk (IMTA) dan apabila melanggar ketentuan tersebut dapat dikenakan sanksi pidana sesuai dengan pasal 185 ayat (1) Undang-Undang Ketenagakerjaan.

Peraturan tersebut diketahui cenderung memudahkan masuknya TKA ke Indonesia walaupun banyak tenaga kerja lokal yang masih membutuhkan lapangan pekerjaan. Pemerintah menyebutkan bahwa TKA dibutuhkan untuk menarik investasi dan tenaga ahli ke Indonesia, namun Peraturan Presiden TKA akan menimbulkan dampak negatif yang lebih besar mengingat keterbatasan kemampuan pemerintah dalam melakukan pengawasan. Wakil Presiden Jusuf Kalla menjelaskan bahwa Peraturan Presiden TKA tidak akan mematikan pekerja lokal. Peraturan Presiden TKA diterbitkan untuk mendongkrak sektor perekonomian di Indonesia. Berdasarkan data Kementrian Ketenagakerjaan, hingga akhir 2017 jumlah TKA di Indonesia sekitar 85.000 orang, angka tersebut tergolong sangat kecil karena kurang dari 0,1\% jika dibandingkan dengan jumlah penduduk Indonesia. Angka TKA di Indonesia jumlahnya masih sangat jauh apabila dibandingkan dengan angka Tenaga Kerja Indonesia (TKI) yang bekerja di luar negeri, sehingga dapat disimpulkan bahwa tidak perlu muncul kekhawatiran akan pengambil alihan lapangan pekerjaan di Indonesia oleh TKA. ${ }^{6}$

Berdasarkan latar belakang diatas diketahui bahwa Peraturan Presiden No. 20 Tahun 2018 rencana penggunaan TKA (RPTKA) sekaligus merupakan izin mempekerjakan TKA, sedangkan dalam Undang-Undang No. 13 Tahun 2003 Tentang Ketenagakerjaan menyatakan bahwa setiap Tenaga Kerja Asing harus memiliki izin tertulis dari Menteri atau pejabat yang ditunjuk (IMTA) setelah

\footnotetext{
${ }^{5}$ Diello Wigra Hardinata, 'Pengawasan Keimigrasian Terhadap Tenaga Kerja AsingDalam Kegiatan Penanaman Modal Asing', Skripsi, (Universitas Sumatera Utara 2018).[8].

${ }^{6}$ Monika Suhayati, 'Kontroversi Perpres Nomor 20 Tahun 2018 Tentang Penggunaan Tenaga Kerja Asing', (2018) 10 Kajian Singkat Terhadap Isu Aktual Dan Strategis.[4].
} 
memiliki RPTKA yang merupakan proses yang memuat sejumlah persyaratan yang harus dipenuhi dan apabila melanggar ketentuan tersebut dapat dikenakan sanksi pidana sesuai dengan pasal 185 ayat (1) Undang-Undang Ketenagakerjaan.

\section{Metode Penelitian}

Dalam penulisan skripsi ini menggunakan tipe penelitian yuridis normatif, yaitu berdasarkan penemuan aturan hukum, prinsip-prinsip hukum, peraturan perundangundangan yang terkait dan literatur yang berkaitan dengan materi pembahasan dalam penulisan skripsi ini. Pembahasan masalah pada skripsi ini dilakukan dengan menggunakan pendekatan konseptual yang beranjak pada pandangan dan doktrindoktrin yang berkembang dalam hukum. Pemahaman akan pandangan dan doktrin tersebut menjadi landasan bagi penulis dalam membangun suatu argumentasi hukum yang nantinya akan digunakan untuk memecahkan isu yang dihadapi. Selain pendekatan konseptual, pendekatan perundang-undangan juga dilakukan dengan menelaah semua undang-undang dan regulasi yang bersangkutan dengan isu hukum yang dikaji. Dengan menggunakan pendekatan Undang-Undang ini akan membuka kesempatan bagi peneliti untuk melihat adanya konsistensi atau kesesuaian antara undang-undangdanUndang-Undang DasaratauantararegulasidanUndang-Undang. ${ }^{7}$

\section{Dokumen Perizinan Yang Harus Dipenuhi Perusahaan Yang Menggunakan TKA}

Menurut Peraturan Presiden No. 20 Tahun 2018 Bab II Pasal 7 ayat 1 setiap Pemberi Kerja TKA yang menggunakan TKA harus memiliki Rencana Penggunaan Tenaga Kerja Asing (RPTKA) yang disahkan Menteri Tenaga Kerja Kerja atau pejabat yang ditunjuk sebelum mempekerjakan TKA.Rencana Penggunaan Tenaga Kerja Asing (RPTKA) berdasarkan Peraturan Menteri Ketenagakerjaan Nomor 10 Tahun 2018 Bab I Pasal 1 adalah rencana penggunaan TKA pada jabatan tertentu yang dibuat oleh Pemberi Kerja TKA untuk jangka waktu tertentu yang disahkan oleh Menteri atau pejabat yang ditunjuk. RPTKA merupakan dokumen awal yang

\footnotetext{
${ }^{7}$ Peter Mahmud Marzuki, Penelitian Hukum Edisi Revisi (Kencana 2005). [133].
} 
digunakan sebagai dasar untuk mendapatkan IMTA. Dengan ketentuan untuk jangka waktu tertentu sesuai dengan perjanjian kerja atau perjanjian pekerjaan. Terkait dengan penggunaan TKA di perusahaan Indonesia, IMTA merupakan salah satu elemen yang krusial sebagai langkah preventif adanya penggunaan TKA yang tidak sesuai kebutuhan dan tujuan awal yang nantinya akan membuat lapangan pekerjaan untuk TKI lebih sedikit karena dikuasai oleh TKA. Namun dengan adanya Peraturan Presiden No. 20 Tahun 2018, IMTA tidak lagi digunakan oleh pemberi kerja atau perusahaan sebagai dokumen perizinan dalam menggunakan TKA. Menurut Peraturan Menteri No. 10 Tahun 2018 tentang Tata Cara Penggunan Tenaga Kerja Asing, Pasal 1 angka 15, notifikasi adalah persetujuan penggunaan TKA yang diterbitkan oleh Direktur Jenderal Pembinaan Penempatan Tenaga Kerja dan Peluasan Kesempatan Kerja sebagai dasar penerbitan ITAS. Pemberi Kerja TKAyang akan mempekerjakan TKA wajib melakukan permohonan Notifikasi kepada Dirjen.

Dalam Peraturan Menteri Ketenagakerjaan No. 10 Tahun 2018 Pasal 19 disebutkan bahwa data calon TKA akan diverifikasi oleh Direktur untuk dinyatakan lengkap dan benar, sehingga Dirjen akan menerbitkan Notifikasi secara online kepada Pemberi Kerja TKA paling lama 2 (dua) hari kerja. Notifikasi tersebut memuat Pemberi Kerja TKA, identitas TKA, lokasi kerja TKA, jangka waktu berlakunya Notifikasi dan kode pembayaran. Pemberi Kerja TKA setelah menerima Notifikasi penggunaan TKA wajib membayar DKP-TKA paling lama 1 (satu) hari kerja. Pemberi Kerja TKA setelah melakukan pembayaran DKPTKA, Dirjen menyampaikan Notifikasi dan bukti pembayaran DKP-TKA kepada Dirjen Imigrasi secara online yang terintegrasi setelah menerima pembayaran DKP-TKA tahun pertama dari Pemberi Kerja TKA untuk proses penerbitan Vitas. Pada Pasal 22 Peraturan Pemerintah Ketenagakerjaan No. 10 Tahun 2018 menuliskan bahwa Pemberi Kerja TKA yang mempekerjakan TKA sebagai anggota direksi atau anggota dewan komisaris dengan kepemilikan saham sesuai dengan ketentuan peraturan perundang-undangan dan pejabat diplomatik dan konsuler pada kantor perwakilan negara asing dikecualikan dari Notifikasi. 


\section{Sanksi Perusahaan Yang Mempekerjakan TKA Yang Tidak Memiliki Izin Menggunakan TKA}

Di dalam Undang-Undang No. 13 Tahun 2003 Tentang Ketenagakerjaan pada Bab XVI mengatur tentang ketentuan pidana dan sanksi administratif untuk diterapkan kepada siapa saja yang melanggar ketentuan sebagaimana yang dimaksud dalam pasal-pasal di dalam Undang-Undang tersebut. Hal ini bertujuan untuk mengatur agar para pihak yang terkait tidak dapat melakukan tindakan sewenangnya sehingga tidak ada pihak lain yang dirugikan, khususnya untuk melindungi para pekerja dari pemerintah atau pejabat yang memiliki kewenangan, ataupun lebih rendah dari pemberi kerja. ${ }^{8}$ Kedudukan hukum ketenagakerjaan di dalam tata hukum Indonesia secara teoritis dipisahkan menjadi 3 (tiga) bidang yaitu, pidana, perdata, dan administrasi (pengawasan). Kedudukan tersebut membawa konsekuensi yuridis bahwa ketentuan peraturanperaturan hukum ketenagakerjaan harus berdasarkan pada teori hukum yang berkaitan dan harus dijalankan secara berhubungan antara satu dengan yang lain. ${ }^{9}$

Sanksi administrasi merupakan sanksi/ hukuman yang diberikan apabila pemberi kerja dan atau TKA yang bekerja di Indonesia tidak mematuhi ketentuanketentuan administrasi yang telah diatur dalam Peraturan Menteri Tenaga Kerja No. 10 tahun 2018. Berdasarkan Pasal 39 ayat 1 (satu) Peraturan Menteri Tenaga Kerja No. 10 tahun 2018, sanksi administrasi terjadi menjadi 4 (empat) macam, yaitu penundaan pelayanan, penghentian sementara proses perizinan TKA, pencabutan notifikasi, dan sanksi lain sesuai dengan peraturan perundang-undangan. Sanksi perdata merupakan sanksi bagi para pihak terkait dalam hubungan ketenagakerjaan yaitu antara pemberi kerja dan pekerja yang didasarkan pada hubungan hukum privat yang tidak dapat memenuhi hak dan kewajiban yang telah disepakati bersama dalam perjanjian kerja. Syarat-syarat kerja, hak, dan kewajiban para pemberi kerja

\footnotetext{
${ }^{8}$ Rival Khasari, 'Penggunaan Tenaga Kerja Asing di Indonesia Ditinjau dari Undang-Undang No. 13 Tahun 2003 tentang Ketenagakerjaan', Skripsi, (Program Sarjana Universitas Airlangga Surabaya 2011).[38].

${ }^{9}$ Asri Wijayanti, Hukum Ketenagakerjaan Pasca Reformasi, Ed 1, (Sinar Grafika 2009).
} 
dan pekerja yang dimuat dalam perjanjian kerja, pada dasarnya harus merujuk pada perjanjian kerja yang sudah dibuat dan disepakati bersama sejak awal. Penerapan sanksi perdata yang pada umumnya dilakukan dalam hukum ketenagakerjaan adalah denda ganti rugi. Sanksi perdata dalam hal penggunaan tenaga kerja asing berfungsi untuk membatasi para pemberi kerja agar tidak bertindak diskriminasi terhadap para tenaga kerja lokal dengan tenaga kerja asing, yang pada umumnya lebih mengutamakan dan memprioritaskan tenaga kerja asing demi kemajuan perusahaannya mengingat tenaga kerja asing memiliki kemampuan yang lebih apabila dibandingkan dengan tenaga kerja lokal. Sanksi perdata berperan sangat penting untuk melindungi para tenaga kerja lokal dari tindakan para pemberi kerja yang bersikap sewenangnya. Apabila terjadi Perselisihan Hubungan Industrial antara pemberi kerja dan pekerja, perundingan dan penyelesaian perselisihan secara damai merupakan salah satu cara yang digunakan untuk menyelesaikan permasalahannya. Sehingga tidak langsung menggunakan hukum yang berlaku agar tidak berlanjut pada pengadilan. Kedudukan hukum ketenagakerjaan dalam hukum pidana adalah pentingnya penerapan sanksi hukum bagi pelanggar peraturan perundang-undangan. Terdapat asas legalitas dalam hukum pidana dimana suatu perbuatan dikatakan melanggar hukum apabila perbuatan tersebut sudah dituangkan dalam suatu undang-undang. Penerapan sanksi harus berdasarkan pada ada dan tidaknya kesalahan yang dapat dibuktikan dengan hubungan kausal antara perbuatan dengan akibat yang terjadi. ${ }^{10}$ Sanksi Pidana merupakan jenis sanksi yang bersifat nestapa yang diancamkan atau dikenakan terhadap perbuatan atau pelaku perbuatan pidana atau tindak pidana yang dapat mengganggu kepentingan umum. ${ }^{11}$

Dengan diterbitkannya Peraturan Presiden No. 20 Tahun 2018 yang menghilangkan IMTA sebagai salah satu syarat mempekerjakan TKA di Indonesia menimbulkan dampak yang cukup signifikan bagi perusahaan maupun tenaga kerja Indonesia. Tidak adanya IMTA berarti menghapuskan kewajiban pemberi kerja

\footnotetext{
${ }^{10}$ Whimo Pitoyo, Panduang Praktis Hukum Ketenagakerjaan (Visimedia 2010).[143].

${ }^{11}$ Adella Zakasri, 'Rencana Penggunaan Tenaga Kerja Asing (RPTKA) Sebagai Izin Menggunakan Tenaga Kerja Asing di Indonesia', Skripsi, (Universitas Airlangga, Surabaya 2019).[29].
} 
sebagaimana yang tertulis dalam pasal 42 Undang-Undang No. 13 Tahun 2003 yang menyatakan bahwa "Setiap pemberi kerja yang mempekerjakan tenaga kerja asing yang memiliki izin tertulis dari Menteri atau pejabat yang ditunjuk", dan mengakibatkan hilangnya sanksi pidanayang sebelumnya ada dan tertulis dalam pasal 185 Undang-Undang No. 13 tahun 2003 yang berbunyi "Barang siapa melanggar ketentuan sebagaimana dimaksud dalam Pasal 42 ayat (1) dan ayat (2), Pasal 68, Pasal 69 ayat (2), Pasal 80, Pasal 82, Pasal 90 ayat (1), Pasal 143, dan Pasal 160 ayat (4) dan ayat (7), dikenakan sanksi pidana penjara paling singkat 1 (satu) tahun dan paling lama 4 (empat) tahun dan/ atau denda paling sedikit Rp 100.000.000,00 (seratus juta rupiah) dan paling banyak Rp 400.000.000,00 (empat ratus juta rupiah)". Disamping itu sanksi yang sebelumnya telah ditetapkan dalam UndangUndang Ketenagakerjaan tidak bisa dijatuhkan karena Peraturan Presiden No. 20 Tahun 2018 menghapuskan kewajiban memiliki IMTA sebagai syarat menggunakan TKA di Indonesia dan memperbolehkan hanya dengan menggunakan RPTKA. Praperadilan adalah satu mekanisme hukum pidana yang dapat ditempuh satu pihak untuk membatalkan perlakuan atau keputusan pihak lain. Perlakuan dan keputusan tersebut yang menjadi objek praperadilan. Praperadilan sendiri diatur dalam Undang-Undang No. 8 Tahun 1981 tentang Hukum Acara Pidana (KUHAP), khususnya Pasal 1 angka 10, Pasal 77 sampai dengan Pasal 83, Pasal 95 ayat (2) dan ayat (5), Pasal 97 ayat (3), dan Pasal 124. Ditinjau dari segi struktur dan susunan peradilan, Praperadilan bukan lembaga pengadilan yang berdiri sendiri maupun sebagai instansi tingkat peradilan yang mempunyai wewenang memberi putusan akhir atas suatu kasus peristiwa pidana. Awal mula kewenangan lembaga praperadilan adalah melakukan pengujian terhadap proses penyidikan dan penuntutan perkara pidana dan menetapkan rehabilitasi dan ganti kerugian atas upaya paksa yang tidak sah. Namun kewenangan tersebut kemudian bertambah dengan lahirnya putusan praperadilan 04/Pid/Prap/2015/PN.JKT. SEL. sehingga tujuan utama praperadilan adalah melakukan pengawasan atas tindakan atau upaya yang dikenakan terhadap tersangka selama ia berada dalam pemeriksaan penyidikan atau penuntutan agar tidakan tersebut benar-benar tidak 
bertentangan dengan ketentuan hukum dan undang-undang.12 Putusan tersebut pada intinya menyebutkan bahwa kewenangan lembaga praperadilan termasuk juga dalam hal menguji sah atau tidaknya penetapan tersangka seseorang. Sehingga upaya hukum perusahaan yang dikenakan sanksi pidana karena mempekerjakan TKA yang tidak memiliki IMTA dapat mengajukan proses praperadilan.

\section{Kesimpulan}

Dokumen perizinan yang harus dipenuhi oleh pemberi kerja yang ingin mempekerjakan Tenaga Kerja Asing (TKA) adalah Rencana Penggunaan Tenaga Kerja Asing (RPTKA) dan IMTA. Namun dengan berlakunya Peraturan Presiden No. 20 Tahun 2018, bagi pemberi kerja yang ingin mempekerjakan Tenaga Kerja Asing (TKA) tidak lagi wajib memiliki IMTA. Pada Peraturan Presiden No. 20 Tahun 2018 disebutkan bahwa selain RPTKA, Notifikasi juga diperlukan sebagai persetujuan penggunaan TKA yang diterbitkan oleh Direktur Jenderal Pembinaan Penempatan Tenaga Kerja dan Perluasan Kesempatan Kerja.

Perusahaan dan setiap pemberi kerja yang mempekerjakan TKA tanpa IMTA tidak bisa dikenakan sanksi pidana. Sebagaimana pada Peraturan Presiden No. 20 Tahun2018yang telahmenghilangkan IMTAsebagaisalah satu syaratmempekerjakan TKA di Indonesia. Jika perusahaan atau pemberi kerja tidak memiliki RPTKA maka dapat dikenakan sanksi pidana, karena pada Peraturan Presiden No. 20 Tahun 2018 RPTKA dianggap sebagai izin mempekerjakan Tenaga Kerja Asing (TKA).

\section{Daftar Bacaan}

\section{Buku}

Peter Mahmud Marzuki, Penelitian Hukum Edisi Revisi (Kencana 2005).

Whimo Pitoyo, Panduang Praktis Hukum Ketenagakerjaan (Visimedia 2010). Asri Wijayanti, Hukum Ketenagakerjaan Pasca Reformasi, Ed 1, (Sinar Grafika 2009).

\footnotetext{
${ }^{12}$ Ulil Azmi, 'Upaya Hukum Terhadap Putusan Praperadilan', Tesis, (Universitas Airlangga 2015).[39].
} 


\section{Jurnal}

Suhandi, 'Pengaturan Ketenagakerjaan Terhadap Tenaga Kerja Asing Dalam Pelaksanaan Masyarakat Ekonomi Asean Di Indonesia’, (2016) 21 Perspektif.

Monika Suhayati, 'Kontroversi Perpres Nomor 20 Tahun 2018 Tentang Penggunaan Tenaga Kerja Asing', (2018) 10 Kajian Singkat Terhadap Isu Aktual Dan Strategis.

\section{Skripsi}

Adella Zakasri, 'Rencana Penggunaan Tenaga Kerja Asing (RPTKA) Sebagai Izin Menggunakan Tenaga Kerja Asing di Indonesia', Skripsi, (Universitas Airlangga, Surabaya 2019).

Diello Wigra Hardinata, 'Pengawasan Keimigrasian Terhadap Tenaga Kerja AsingDalam Kegiatan Penanaman Modal Asing', Skripsi, (Universitas Sumatera Utara 2018).

Rival Khasari, 'Penggunaan Tenaga Kerja Asing di Indonesia Ditinjau dari UndangUndang No. 13 Tahun 2003 tentang Ketenagakerjaan', Skripsi, (Program Sarjana Universitas Airlangga Surabaya 2011).

Imroatus Sa'adah, 'Indonesia Dalam Masyarakat Ekonomi ASEAN (MEA) Dalam Perspektif Ibnu Khaldun', Skripsi,(Universitas Islam Negeri Sunan Kalijaga 2018).

Ulil Azmi, 'Upaya Hukum Terhadap Putusan Praperadilan',Tesis, (Universitas Airlangga 2015).

HOW TO CITE: Ahmad Fairus, 'Keberlakuan Sanksi Pidana terhadap Perusahaan yang Tidak Memiliki Izin Menggunakan Tenaga Kerja Asing' (2019) Vol. 2 No. 6 Jurist-Diction. 
--halaman ini sengaja dibiarkan kosong-- 